\title{
Morphoanatomy of striated myofibers in streptozotocin-induced diabetic wistar rats: assuaging effect of combined doses of Vernonia amygdalina and Azadirachta indica
}

\author{
Yama, O.E. ${ }^{1}$, Adeteye, O.V. ${ }^{2}$, Kusemiju, T.O. ${ }^{2}$, Avidime, O.M. ${ }^{3},{ }^{*}$ Danboyi T. ${ }^{3}$, \\ Odetola, A.A. ${ }^{2}$, Mohammed K.A.
}

\begin{abstract}
Objective: This study aimed to evaluate the effects of Azadirachta indica and Vernonia amygdalina extracts on the morphoanatomy of striated myofibrils in diabetic rat models.

Methodology: Thirty Wistar rats randomly assigned into 5 groups of 6 rats/group were used. Group A received distilled water only, B (herbal) received A. indica $(500 \mathrm{mg} / \mathrm{kg} / \mathrm{day})$ and $V$. amygdalina (400 $\mathrm{mg} / \mathrm{kg} /$ day) simultaneously, $\mathrm{C}$ were diabetic rats, D were diabetic rats treated with herbal extracts combined and E, diabetic rats treated with metformin. Diabetes was induced with streptozotocin (70 $\mathrm{mg} / \mathrm{kg}$ ). Muscles glutathione peroxidase (GPx) and blood glucose levels were determined. The rats were sacrificed at the end of 60days treatment. The quadriceps femoris muscle harvested for histology.
\end{abstract}

Results: Diabetic herbal treated rats became euglycemic by the end of 8 weeks. GPx activity was significantly $(p<0.05)$ elevated compared to control. The histology of skeletal muscle fibers of the diabetic rats treated with herbal formulation and metformin showed minimal level of damage.

Conclusions: The findings in this study showed that the herbal formulation could be used in treatment of diabetes and in ameliorating the associated muscular cytoarchitectural alterations.

Keywords: diabetic, extract, glutathione, peroxidase

*Corresponding author

Danboyi T.

ORCID-ID: http://orcid.org/0000-0003-2550-6158

E-mail: timothy.danboyi@kasu.edu.ng.

\footnotetext{
${ }^{1}$ Department of Human Anatomy, Kaduna State University, Kaduna, Nigeria

${ }^{2}$ Department of Morbid Anatomy, Faculty of Basic Medical Sciences, University of Lagos, Lagos, Nigeria;

${ }^{3}$ Department of Human Physiology, Kaduna State University, Kaduna, Nigeria.
} 


\title{
Morphoanatomie des Myofibres Striées Chez les Rats Diabétiques Wistar Induits par la Streptozotocine: Effet Dissuasif des Doses Combinées de Vernonia amygdalina et Azadirachta indica
}

\author{
Yama, O.E. ${ }^{1}$, Adeteye, O.V. ${ }^{2}$, Kusemiju, T.O. ${ }^{2}$, Avidime, O.M. ${ }^{3},{ }^{*}$ Danboyi T. ${ }^{3}$, \\ Odetola, A.A. ${ }^{2}$, Mohammed K.A. ${ }^{3}$
}

\section{Résumé}

Objectif: Cette étude visait à évaluer les effets des extraits d'Azadirachtaindica et de Vernoniaamygdalina sur la morphoanatomie des myofibrilles striées dans des modèles de rats diabétiques.

Méthodes: Trente rats Wistar répartis au hasard en 5 groupes de 6 rats/groupe ont été utilisés. Le groupe A n'a reçu que de l'eau distillée, B (à base de plantes) a reçu A. Indica (500 mg/kg/jour) et V. amygdalina (400 $\mathrm{mg} / \mathrm{kg} /$ jour $)$ simultanément, $C$ rats werediabétique, $\mathrm{D}$ étaient des rats diabétiques traités avec des extraits de plantes combinés et $\mathrm{E}$, des rats diabétiques traités avec de la metformine. Le diabète a été induit par la streptozotocine $(70 \mathrm{mg} / \mathrm{kg}$ ). Les muscles glutathion peroxydase (GPx) et la glycémie ont été déterminés. Les rats ont été sacrifiés à la fin du traitement de 60 jours. Le muscle quadriceps fémoral prélevé pour l'histologie.

Résultats: Les rats diabétiques traités aux herbes sont devenus euglycémiques au bout de 8 semaines. L'activité GPx était significativement $(\mathrm{p}<0,05)$ élevée par rapport au contrôle. L'histologie des fibres musculaires squelettiques des rats diabétiques traités avec une formulation à base de plantes et de la metformine a montré un niveau minimal de dommages.

Conclusion: Les résultats de cette étude ont montré que la formulation à base de plantes pouvait être utilisée dans le traitement du diabète et dans l'amélioration des altérations cytoarchitecturales musculaires associées.

Mots-clés: Diabétique, extrait, glutathion, peroxydase

*Corresponding author

Danboyi T.

ORCID-ID: http://orcid.org/0000-0003-2550-6158

E-mail: timothy.danboyi@kasu.edu.ng.

${ }^{1}$ Department of Human Anatomy, Kaduna State University, Kaduna, Nigeria

${ }^{2}$ Department of Morbid Anatomy, Faculty of Basic Medical Sciences, University of Lagos, Lagos, Nigeria;

${ }^{3}$ Department of Human Physiology, Kaduna State University, Kaduna, Nigeria. 


\section{INTRODUCTION}

Skeletal muscle tissue is the major amino acids reservoir in the body and plays an essential role in the regulation of nitrogen balance and glycemic homeostasis $(1,2)$. Alongside increased proteolysis, the inability to repair damaged skeletal muscle is a characteristic feature of uncontrolled diabetes (3). In diabetes, the hyperglycemic condition is found to promote lipid peroxidation of low-density lipoprotein (by a superoxide-dependent pathway) resulting in free radicals' generation and therefore increased oxidative stress (4). The extra-cellular proteins, such as elastin, laminin and collagen are the major targets for these free radicals. They are first broken down into glycoproteins (due to the chronic hyperglycemia) and then further into fragments (5). These alterations in some tissues are associated with the development of complications such as cataracts, microangiopathy, atherosclerosis and nephropathy.

Types 1 and 2 diabetes are characterized by a loss of insulin action in skeletal muscle, leading to changes in glucose and lipid metabolism, gene expression and protein phosphorylation (6). In type-2 diabetes in which cells do not respond to insulin many different drugs are developed taking into consideration possible disturbances in carbohydratemetabolism. The degradation of carbohydrates is inhibited, thereby reducing glucose absorption by the cells. To enhance glucose uptake by peripheral cells, biguanides such as metformin are used. Although several therapies are employed for treatment, there are certain limitations due to high cost and side effects $(7,8)$. In the quest to proffer a lasting solution to this ominous and insidious disease, a pragmatic idea of using the combined effect of $A$. indica and $V$. amygdalina extract was developed to ameliorate and manage it (9). It has been proven that $A$. indica parts (especially, its leaves) have high efficacy in treating DM with no side effects. Similarly, studies conducted using streptozotocin (STZ)-induced diabetic animals showed that $V$. amygdalina administration decreased blood glucose by $50 \%$ compared to untreated diabetic animals (10). Since $V$. amygdalina has been a reliable treatment for various metabolic disorders (especially diabetes mellitus) and it is sumptuous, with highly nutritive and healing values, combining its leaves with other herbal extracts such as $A$. indica may enhance the management of DM when consumed.

In the present study we investigated the anti-diabetic effects of combined herbal formulation of $A$. indica and $V$. amygdalina leaves in STZ-induced diabetic rat models. The work involved histological studies on skeletal muscle, as well as estimation of the antioxidant enzyme glutathione peroxidase (GPx) in the tissues.

\section{MATERIALS AND METHODS Animals}

Thirty albino rats of Wistar strain (both sexes) were used in the study. The rats (8-10 weeks old) weighing an average of $177 \mathrm{~g}$ were housed in wire gauze cages with alternating 12-hr natural light/dark cycles at room temperature in the animal house of the Department of Anatomy, University of Ilorin. They were fed with rat pellets and water ad libitum and were allowed to acclimatize for two weeks before beginning the experiment.

\section{Botanical formula}

The botanical formula consists of the leaves of $A$. indica and $V$. amygdalina as follows: $V$. amygdalina $(400 \mathrm{mg} / \mathrm{kg})$ and $A$. indica $(500$ $\mathrm{mg} / \mathrm{kg}$ ) in the ratio 5:4. The crude extract of these herbs were prepared by soxhlet extraction using ethanol. The concentrations of the extract (diluted in distilled water) were prepared based on the rat's body weight and administered orally using an orogastric metal canula.

\section{Procurement and taxonomy of the plants}

Fresh leaves of $A$. indica (neem) were collected in the premises of the Department of Anatomy, University of Ilorin, Nigeria and that of $V$. amygdalina (bitter leaf) were collected at Okeodo area in Ilorin, Nigeria. Botanical identification was done at the Herbarium, Department of Botany, University of Ilorin. The samples collected were dried under shade, to protect the active constituents from destruction due to radiation, for a period of 3 weeks. After this period, the dried leaves were ground to fine powder and weighed using an analytical weighing balance (FA2104A, Gallenkomp, England).

\section{Pharmacomathy of the extracts}

Fresh leaves of $A$. indica and $V$. amygdalina were air-dried at room temperature. A total of $1690 \mathrm{~g}$ and $3076 \mathrm{~g}$ of V. amygdalina and A. indica respectively of the dry leaf powder was extracted after pounding and sieving the leaves. Thereafter, the powders of the two leaves were dissolved in 2 liters of $70 \%$ ethanol in different 
containers overnight. After 3 days, the fluid was decanted and the filtrates were poured in beakers and placed in the oven, regulated at $40^{\circ} \mathrm{C}$ (so that the active constituents are not denatured) for evaporation. It was later transferred into an evaporating dish. The evaporation was continued at a temperature of $40^{\circ} \mathrm{C}$ until all the ethanol was gone leaving a greenish paste-like, extract of $V$. amygdalina and $A$. indica. Each of the extracts were kept separately and temporarily in aluminum foil at a temperature of $4^{\circ} \mathrm{C}$.

\section{Treatment groups and experimental design}

The animals were randomly assigned into 5 groups [A (Control), B (Herbal only), C (Diabetic), D (Diabetic + Herbal) and E (Diabetic + Metformin)] (Table 1$)$ of $6(n=6)$ rats each.

Rats in the control group were fed $4 \mathrm{ml}$ distilled water/kg body weight [b.wt.]/day, those in Group B were treated with the herbal formulation comprising combined extracts of $A$. indica $(500$ $\mathrm{mg} / \mathrm{kg}$ b.wt./day) and $V$. amygdalina $(400 \mathrm{mg} / \mathrm{kg}$ b.wt./day). Group $\mathrm{C}$ rats were induced diabetes using STZ (70 mg/kg b.wt.). Diabetes was also induced in rats in Groups D and E using STZ (as in Group C). Group D rats were subsequently treated with the herbal formulation as in Group B while Group E with Metformin at $350 \mathrm{mg} / \mathrm{kg}$ b.wt./day (11).

The dosages of the plant extracts were as determined from preliminary work in our laboratory.

\section{Induction of diabetes and the placebo effect}

Diabetes was induced using STZ (Sigma, MO, USA) at $70 \mathrm{mg} / \mathrm{kg} \mathrm{b.wt.} \mathrm{in} 0.1 \mathrm{M}$ citrate buffer at $\mathrm{pH} 4.5$. It was injected intraperitoneally (i.p) to overnight fasted rats (12). The rats were allowed access to food and water after injection. Sustained hyperglycemia developed about 72-hr post-STZ injections. Rats with fasting blood glucose of $\geq 250 \mathrm{mg} / \mathrm{dL}$ were considered hyperglycemic (12). The non-diabetic (group A) and herbal treated (group B) rats received a single i.p injection of citrate buffer ( $1 \mathrm{ml} / \mathrm{kg}$ b.wt.) placebo of laboratory preparation.

\section{Treatment duration}

Animals received the combined herbal formulation for 60 days. A. indica was given at $500 \mathrm{mg} / \mathrm{kg}$ b.wt./day; $V$. amygdalina at 400 $\mathrm{mg} / \mathrm{kg}$ b.wt./day and metformin at $350 \mathrm{mg} / \mathrm{kg}$ b.wt./day for the same period.

\section{Blood glucose and body weight measurement \\ Blood glucose was measured in fasted rats at 9.00-10.00 h. using One Touch Ultra 2}

Glucometer and its strips (Lifescan, CA, USA). Blood was obtained from the dorsal vein of the tail (13). At day 0 of $V$. Amygdalina, A. indica and Metformin treatment, blood glucose was monitored every alternate hour $\left(1^{\text {st }}, 3^{\text {rd }}, 5^{\text {th }}\right.$ and $7^{\text {th }}$ $\mathrm{h})$; then each day in the first week; and thereafter, twice in a week, for 8 weeks.

Body weights of the rats were taken prior to the induction of hyperglycemia, at day 0 of $V$. Amygdalina and $A$. indica treatments and on a daily basis thereafter, for 8 weeks, using a weighing balance.

\section{Tissue homogenization}

At the end of $60^{\text {th }}$ day of treatment, the animals were euthanized under diethyl ether anesthesia and sacrificed. Laparotomy performed and blood collected from the inferior vena cava for protein analysis. Subsequently, the skeletal muscle (quadriceps femoris) were harvested and fixed in $40 \%$ formalin solution. A portion were also homogenized in phosphate buffer (0.1 M, pH 7.4), for the estimation of GPx. Muscle GPx activity was estimated by the method of Paglia and Valentrine (14), using the reagent kit from Randox Laboratories Ltd; (Antrim, U.K). The homogenate allowed to attain room temperature and $0.5 \mathrm{ml}$ of drabkins solution was added to the homogenate. The timer was started simultaneously with the addition of R2; the spectrophotometer was blanked with distilled water. The initial absorbance of both the test and blank was read after $1 \mathrm{~min}$ and again after 1 and 2 minutes at $340 \mathrm{~nm} . \mathrm{GPx}=$ [change in abs/min $\mathrm{x}$ 8412] $\mathrm{u} / \mathrm{L}$.

\section{Tissue processing}

Part of the harvested skeletal muscle was fixed in Bouin's fluid and processed for histological studies. The muscle tissues were fixed in $10 \%$ formalin for 12 hours. It was then dehydrated, using ascending grades of alcohol, from $30 \%$ to absolute alcohol III; the tissue stayed about 2 hours in each grade of alcohol. Clearing was carried out overnight in xylene I for 6 hours and in xylene II for 1 hour. It was then infiltrated with paraffin wax I and II for 30 minutes at $58-60^{\circ} \mathrm{C}$ followed by embedding with Leuchart's embedding boxes ( $2 \mathrm{~L}$-shaped pieces of metal, usually brass). Sectioning was done with Leica's rotary microtome (Leica RM 2135, Germany) at 5 microns thickness adjustment. The tissues were mounted on slides using DPX as mountant, then stained via the normal procedure for Masson's trichrome stains which involved dissolving the ponceau $2 \mathrm{R}$ in $100 \mathrm{ml} 1 \%$ acetic acid and the acid fuchsin in $50 \mathrm{ml}$ acetic acid. 
Light microscopic studies were carried out using an optical compound microscope (Uniscope, Japan).

\section{Data analysis}

Statistical analysis was carried out using Statistical Package for Social Sciences (SPSS) 23.0 (SPSS Inc., Chicago, USA). Data were expressed as mean ( \pm S.E.M). Means were compared using the student's t-test and $p$ value < 0.05 was considered significant.

Ethical considerations: All procedures in this investigation conformed to the guiding principles for research involving animals as recommended by the Declaration of Helsinki and the Guiding Principles in the Care and Use of Animals (15) and were approved by the Institutional Committee on the Use and Care of Animals in conformity with international acceptable standards.

\section{RESULTS}

At the end of experiment, diabetic group (group C) showed significant weight loss $(104.8 \pm 17.03 \mathrm{~g})$ compared to the control group (A group) (215.4 $\pm 12.24 \mathrm{~g} ; p<0.05)$. There were no significant differences in the body weight between control and other groups: B - Herbal only $(235.2 \pm 15.96 \mathrm{~g})$, D - Diabetic+ Herbal (197.4 $\pm 6.41 \mathrm{~g})$ and E - Diabetic+ Metformin (244.7 $\pm 29.84 \mathrm{~g})$ (Figure 1).

The mean blood glucose concentrations were $117.1 \pm 11.86 \mathrm{mg} / \mathrm{dl}$ in the control group, $127.1 \pm 15.95 \mathrm{mg} / \mathrm{dl}$ in Herbal only, 446.7 \pm 66.86 $\mathrm{mg} / \mathrm{dl}$ in the Diabetic group, $293.0 \pm 57.17 \mathrm{mg} / \mathrm{dl}$ in Diabetic+ Herbal, and $226.3 \pm 44.64 \mathrm{mg} / \mathrm{dl}$ in Diabetic+ Metformin. The value in the diabetic group was significantly higher than in the control group $(p<0.05)$, while there were no significant differences between control and other groups (Figure 2).

The mean GPx enzyme activities were $4327.5 \pm 26.87 \mathrm{IU} / \mathrm{g}$ in control, 4448.0 \pm 201.75 $\mathrm{IU} / \mathrm{g}$ in Herbal only, 2041.0 $\pm 7.58 \mathrm{IU} / \mathrm{g}$ in Diabetic group, 3817.50 $\pm 61.66 \mathrm{IU} / \mathrm{g}$ in Diabetic+ Herbal and 3621.50 $\pm 209.66 \mathrm{IU} / \mathrm{g}$ in Diabetic+ Metformin, as illustrated in the bar chart (Figure 3). The value in the diabetic group was significantly less than in the control group $(p<0.05)$, while there were also no marked significant differences in the mean enzyme activities between control and other groups.

In the light microscopic annotations, the diabetic group showed reduced number of nuclei, shrunken and indistinct fibers of the perimysium compared to control and herbal treated normal rats. The histology of the herbal and metformin treated diabetic rats were fairly similar to control (figure 4).

\section{DISCUSSION}

In a diabetic, carbohydrate diet usually stimulates the appetite center and disturbs energy balance (16). Weight loss resulting from intentional decrease in caloric intake (17-21) normalizes this imbalance, reduces insulin concentrations and favors utilization of stored fat as fuel in addition to reducing significantly insulin resistance (22) preventing the likely occurrence of diabetes. On the other hand, unintentional weight loss typified in diabetic subjects with impaired glucose metabolism does not achieve this goal of maintaining balance. The breakdown in muscle tissue, fluid loss (micturition) and dehydration from hyperglycemia in addition to reduction in fat and lean mass that exacerbate risk of cachexia (23) are amongst the reasons for the unhealthy weight loss. Weight monitoring therefore is an indirect way of assessing responsiveness to management of diabetic patient using specific oral hypoglycemic regimens. In this study, the gross morphological body weight discrepancies in the animals were closely observed during the period of drug and herb (A. indica and $V$. amygdalina) administration. At the end of experiment increases in body weights were observed in all the groups except group C (diabetic group) which showed significant unintentional weight loss compared to control group (A group) $(p<0.05)$. However, when the weight disparities in the diabetic rats treated with the herbal combination were compared to those treated with metformin, it revealed interesting alternating patterns. There were sharp increases (peaks) in mean weights on the $2^{\text {nd }}$ and $6^{\text {th }}$ week followed by weight losses in the succeeding weeks (nadirs) in the metformin treated. This finding portrays aberrations in the glucose metabolic pathways in these rats (24). The herbal treated group on the other hand, had variations comparable to baseline control showing a better 'glucose handling capability'. Our finding is similar to previous work done by researchers using Acacia nilotica leaves extract (25). The increase in body weight is probably attributed to protein anabolic effect and reversal of gluconeogenesis and glycogenolysis by the improvement of insulin secretion as a result of insulinotropic effect (24) of our herbs and metformin.

Since oral hypoglycemic agents are substances that decrease the level of glucose in the blood and are used in the treatment of diabetes 
(26). Therefore, the best verification of the quality of any oral hypoglycemic agent would be assessing its sugar regulating potentials in diabetic subjects who use it as a sole means of glycemic control. Hence the capabilities of these agents in handling blood glucose in diabetic rat models at different stipulated treatment periods were compared in this study. Initially, the group made diabetic (STZ-treated animals), became hyperglycemic (compared to control) before the end of the $1^{\text {st }}$ week (Figure 2) and by the end of week 1 (to $8^{\text {th }}$ week), virtually all the animals became consistently hyperglycemic indicating optimal method of induction of diabetes. This method is similar to the technique employed by the researchers Zhang and Tan (27). The diabetic rats administered the herbal combination and metformin became euglycemic by the end of 8 weeks treatment period. Although the herbal combination showed glycemic levels slightly closer to control than metformin by $8^{\text {th }}$ week, the latter had a better overall interval handling of blood sugar levels from the $1^{\text {st }}$ to $7^{\text {th }}$ weeks of treatment as variation peaks compared to normal baseline (Figure 2).

The enzyme GPx is an antioxidant enzyme that protects cells from oxidative damage induced by reactive oxygen species, acting as a free radical scavenger (28). The experimental diabetic rats showed critically low enzyme activity compared to control (Figure 3) and therefore a compromised ability at detoxifying free radicals will is expected. After 8 weeks, the enzyme GPx activities in the normal rats treated with distilled water (group A) were significantly not different $(p>0.05)$ from normal rats treated with combined extracts (group B), but were significantly $(p<0.05)$ higher in diabetic rats treated with the herbal combination (group D), than in the diabetic untreated group (group C). Values were also elevated (but not significant $p>$ 0.05 ) in the diabetic rats treated with metformin compared to the diabetic untreated reference. Therefore, suffice to say that the herbal combination had better maintenance of redox homeostatic milieu than conventional metformin in treating diabetes. Consequently, it might not be surprising that the observed skeletal muscle fibers in the diabetic animals showed more overt histological alterations. Their muscles fibers were shrunken, distorted with paucity of nuclei and brittleness of the perimysium (Plate 3C). In the diabetic rats treated with the herbal formulation (Plate 4D) and metformin (Plate 5E), the histology showed minimal level of damage to the skeletal muscle fibers. Conversely, those normal rats treated with the herbs alone (Plate
2B) had a similar histological pattern as those of control treated with distilled water.

The major hindrance in the amalgamation of herbal medicine and modern medical practices is the lack of lucid scientific/clinical data proving their efficacy and safety. Therefore, in this present study there is the need to conduct further extensive research on the herbal formulation to develop simple bioassays for biological standardization and various animal models for toxicity and safety studies. It is also salient to establish the active components from these plant extracts.

\section{CONCLUSION}

In conclusion, the findings have shown that combined $A$. indica and $V$. amygdalina herbal decoction has anti-diabetic effect in rats; hence it can be used in ameliorating the crippling disease. The herbal treated diabetic rats' maintained better morphology of skeletal myofibers, weight and antioxidant property compared to those treated with metformin a conventional oral hypoglycemic agent.

Acknowledgement: The funding of this research work was entirely sponsored by individual financial contributions, no external source of funding was obtained.

Conflicts of interest: No conflict of interest to declare.

\section{REFERENCES}

1. Castaneda C. Muscle wasting and protein metabolism. J Anim Sci. 2002; 80(2): 98-105.

2. McCroskery S, Thomas M, Hennebry A. Improved muscle healing through enhanced regeneration and reduced fibrosis in myostatinnull mice. J Cell Sci. 2005; 118: 3531-41.

3. Aragno M, Mastrocola R, Catalano MG, Brignardello E, Danni O, Boccuzzi G. Oxidative Stress Impairs Skeletal Muscle Repair in Diabetic Rats. Diabetes. 2004; 53: 1082-8.

4. Maritim C. Sanders RA, Watkins III JB. Diabetes, Oxidative Stress, and Antioxidants: A Review. J Biochem Mol Toxic. 2003; 17(1): 24-38.

5. Wolff SP, Dean RT. Glucose autoxidation and protein modification: the potential role of autoxidative glycosylation in diabetes. Biochem J. 1987; 245: 243-50.

6. Yechoor VK, Patti M, Saccone R, Kahn CR. Coordinated patterns of gene expression for substrate and energy metabolism in skeletal muscle of diabetic mice. Proc Natl Acad Sci U S A. (PNAS). 2002; 99(16): 10587-92.

7. Joseph B, Jini D. Insight into the Hypoglycemic Effect of Traditional Indian Herbs used in the treatment of Diabetes. Res J Med Plant. 2011; 
5(4): 352-76.

8. Dey L, Atele SA, Yuan CS. Alternative therapies for Type 2 Diabetes Mellitus. Altern Med Rev. 2002; 7(1): 52-3.

9. Patrick EE. Antidiabetic efficacy of combined extracts from two continental plants Azadirachta indica and Vernonia amygdalina. Amer $\mathbf{J}$ Biochem Biotech. 2008; 4(3): 239-44

10. Nwanjo HU. Efficacy of aqueous leaf extract of Vernonia amygdalina on plasma lipoprotein and oxidative status in diabetic rat models. Nig J Physiol Sci. 2005; 20(1-2): 30-42.

11. Akinola OB, Zatta L, Dosumu OO, Akinola OS, Dini L, Caxton-Martins EA. Ameliorative Effects of Ethanolic Leaf Extract of Azadirachta indica on Renal Histologic Alterations in Streptozotocin-Induced Diabetic Rats. The Amer J Chinese Med (AJCM). 2011; 39(5): 903-16.

12. Akinola OB, Caxton-Martins EA, Dini L. Chronic Treatment with Ethanolic Extract of the Leaves of Azadirachta indica Ameliorates Lesions of Pancreatic Islets in streptozotocin Diabetes. Int J Morphol. 2010; 28(1): 291-302.

13. Atangwho IJ, Ebong PE, Eyong EU, Egbung GE. Combined Extracts of Vernonia Amygdalina and Azadirachta Indica May Substitute Insulin Requirement in the Management of Type I. Res J Med Med Sci. 2010; 5(1): 35-9.

14. Paglia DE, Valentine WN. Studies on the quantitative and qualitative characterization of erythrocyte glutathione peroxidase. J Lab Clin Med. 1967; 70: 158-69.

15. American Physiological Society. Guiding principles for research involving animals and human beings. Am J Physiol Regul Integr Comp Physiol. 2002; 283: 281-83.

16. Boden G, Sargrad K, Homko C, Mozzoli M, Stein TP. Effects of a low- carbohydrate diet on appetite, blood glucose levels, and insulin resistance in obese patients with type 2 diabetes. Ann Intern Med. 2005; 142: 403-11.

17. Samaha FF, Iqbal N, Seshadri P, Chicano KL, Daily DA, McGrory J, Williams T, Gracely EJ, Stern L: A low-carbohydrate as compared with a low-fat diet in severe obesity. N Eng JMed. 2003; 348: 2074-81.

18. Foster GD, Wyatt HR, Hill JO, McGuckin BG, Brill C, Mohammed BS, Szapary PG, Rader DJ, Edman JS: A randomized trial of lowcarbohydrate diet for obesity. NEng JMed. 2003;
348: 2082-90.

19. Brehm JB, Seeley RJ, Daniels SR, D'Alessio DA. A randomised trial comparing a very low carbohydrate diet and calorie-restricted low-fat diet on body weight and cardiovascular risk factors in healthy women. J Clin Endocrinol. 2003; 88: 1617-23.

20. Sondike SB, Copperman N, Jacobson MS: Effects of a low-carbohydrate diet on weight loss and cardiovascular risk factors in overweight adolescents. J Pediatr. 2003; 142: 253-8.

21. Yancy WS, Olsen MK, Guyton JR, Bakst RP, Westman EC: A low-carbohydrate ketogenic diet versus a low-fat diet to treat obesity and hyperlipidemia. Ann Int Med. 2004; 140: 769-77.

22. Boden G, Sargrad K, Homko C, Mozzoli M, Stein TP: Effects of a low- carbohydrate diet on appetite, blood glucose levels, and insulin resistance in obese patients with type 2 diabetes. Ann Intern Med. 2005; 142: 403-11

23. Morley JE, Thomas DR, Margaret-Mary GW. Cachexia: pathophysiology and clinical relevance. Amer J Clin Nutr. 2006 April; 83(4): 735-43

24. Kim JS, Jung BJ, Choi CW, Kim SC. Hypoglycemic and antihyperlipidemic effect of four Korean Medicinal plants in alloxen induced diabetic rats. Am J Biochem Biotechnol. 2006; 2: 154-60.

25. Munazza Asad, Muhammad Aslam, Tahir Ahmad Munir, Amina Nadeem. Effect of Acacia nilotica leaves extract on hyperglycaemia, lipid profile and platelet aggregation in streptozotocin induced diabetic rats. J Ayub Med Coll Abbottabad. 2011;23(2): 2-7.

26. Oral hypoglycemic agent. The free dictionary. Princeton University, Farlex Inc. copyright 2019. A v a i l a b l e a t http://www.thefreedictionary.com/hypoglycemi c+agent. Accessed on $4^{\text {th }}$ March 2019

27. Zhang XF, Tan BKH. Effects of an Ethanolic Extract of Gynura procumbens on Serum Glucose, Cholesterol and Triglyceride Levels in Normal and Streptozotocin-Induced Diabetic Rats. Singapore Med J. 2000; 41(1): 9-13.

28. Rudin CM, Yang Z, Schumaker LM, Vander Weele DJ, Newkirk K, Egorin MJ. Inhibition of glutathione synthesis reverses Bcl-2- mediated cisplatin resistance. Cancer Res. 2003; 63: 312-8. 
Table 1: Experimental design

\begin{tabular}{|c|c|c|}
\hline Group batches: $(n=30)$ & $\begin{array}{l}\text { No. of } \\
\text { animals }\end{array}$ & Treatment \\
\hline $\begin{array}{l}\text { A: Non-diabetic (control) received a } \\
\text { single intraperitoneal (i.p) injection of } \\
\text { citrate buffer ( } 1 \mathrm{ml} / \mathrm{kg} \text { b.wt.) }\end{array}$ & 6 & $4 \mathrm{ml}$ distilled water \\
\hline $\begin{array}{l}\text { B: Herbal only received citrate buffer } \\
\text { (as in A) }\end{array}$ & 6 & $\begin{array}{l}\text { Herbal compound }=V \text {. amygdalina }(400 \\
\mathrm{mg} / \mathrm{kg} \text { b.wt. /day) and } A . \text { indica }(500 \mathrm{mg} / \mathrm{kg} \\
\text { b.wt. /day) }\end{array}$ \\
\hline $\begin{array}{l}\text { C: Diabetic (diabetic reference) Injected } \\
\text { i.p streptozotocin (STZ) at } 70 \mathrm{mg} / \mathrm{kg} \\
\text { b.wt. in } 0.1 \mathrm{M} \text { citrate buffer at } \mathrm{pH} 4.5 \text {. }\end{array}$ & 6 & $4 \mathrm{ml}$ distilled water \\
\hline D: Diabetic + Herbal & 6 & $\begin{array}{l}\text { Injected STZ (as in C) and subsequently } \\
\text { treated orally with herbal compound as in B } \\
\text { Injected STZ (as in C) and subsequently }\end{array}$ \\
\hline $\mathbf{E}:$ Diabetic + Metformin & 6 & $\begin{array}{l}\text { treated orally with metformin at } 350 \mathrm{mg} / \mathrm{kg} \\
\text { b.wt./day }\end{array}$ \\
\hline
\end{tabular}

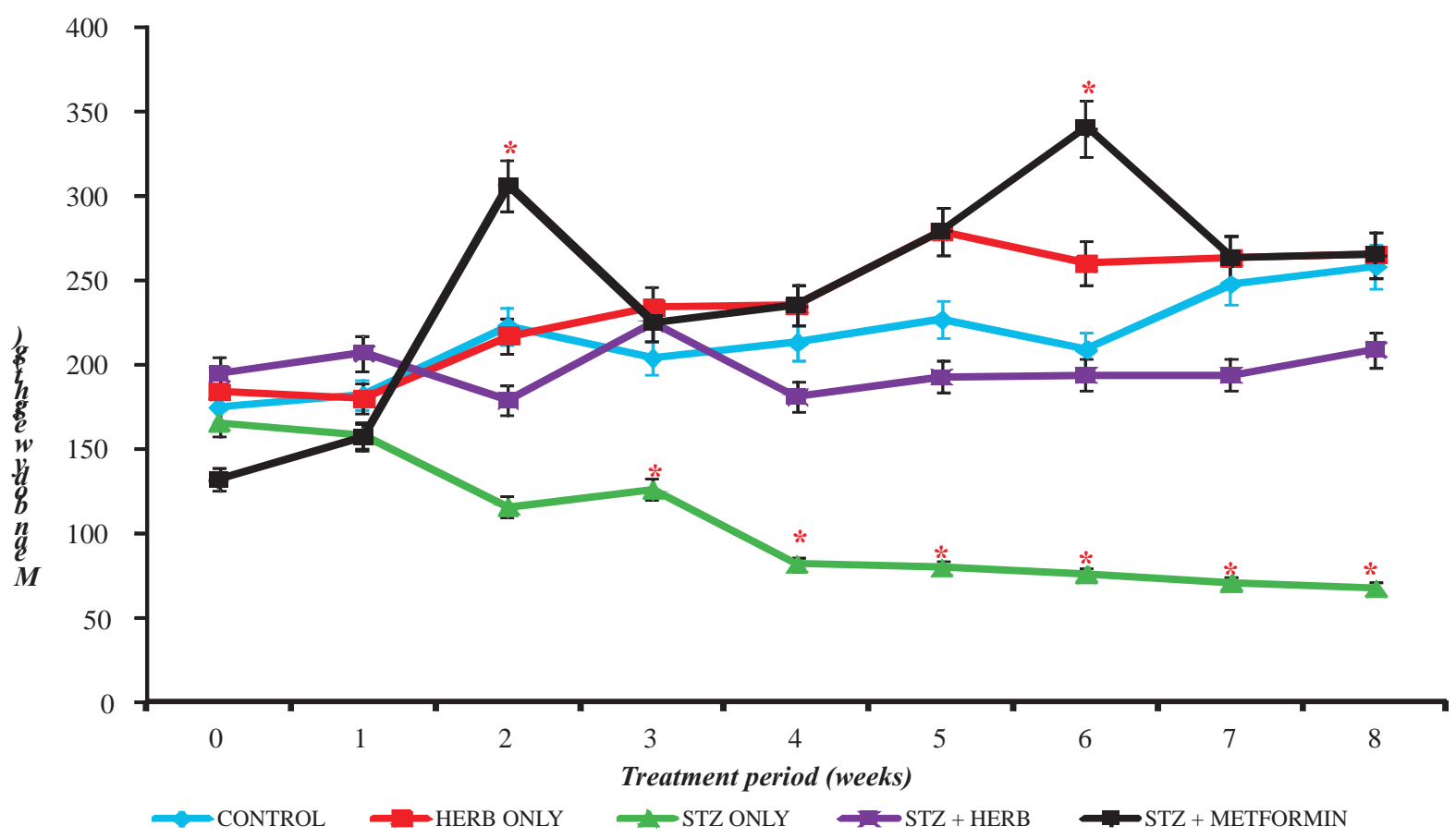

Figure 1: Changes in body weights of the rats from week 0 to week 8.

Values are expressed as Mean \pm SEM; $* p<0.05$ significantly different from control;

Groups: [A (Control), B (Herbal only), C (Diabetic), D (Diabetic + Herbal) and E (Diabetic + Metformin)]. 


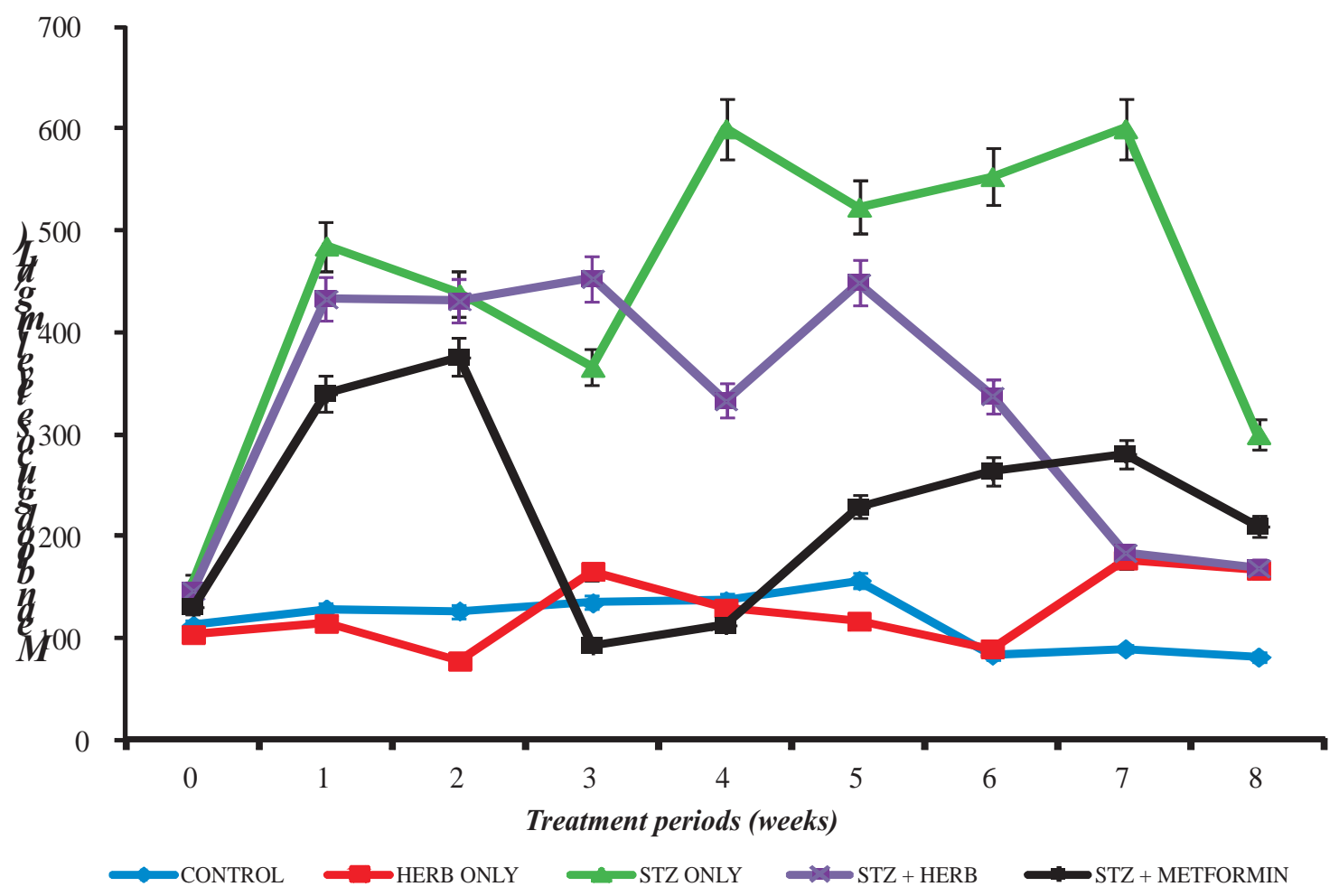

Figure 2: Blood glucose concentrations of the rats from week 0 to week 8 ; Values are expressed as Mean $\pm S E M ; * \quad p<0.05$ significantly different from control. STZ: Streptozotocin induced diabetes; Groups: [A (Control), B (Herbal only), C (Diabetic), D (Diabetic + Herbal) and E (Diabetic + Metformin)]

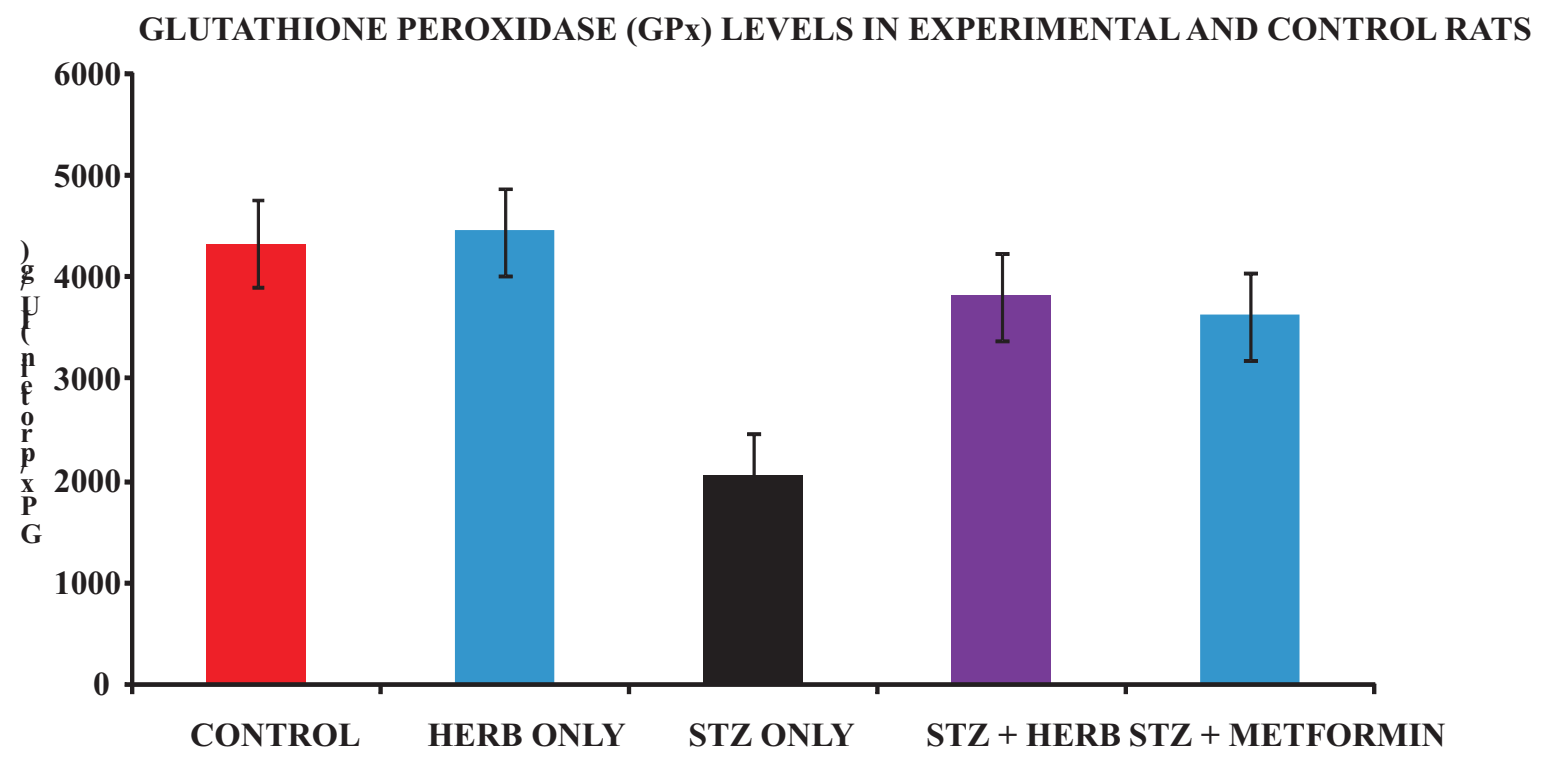

Figure 3: Muscle glutathione peroxidase (GPx) activities in experimental and control rats.

Values are expressed as Mean $\pm S E M ; * p<0.05$ significantly different from contro $\quad l$. STZ: Streptozotocin induced diabetes; Groups: [A (Control), B (Herbal only), C (Diabetic), D (Diabetic + Herbal) and E (Diabetic + Metformin)]

Res. J. of Health Sci. Vol 8(2), April/June 2020 
Histo-morphological effect of V. amygdalina and A. indica on diabetic Wistar rats Yama et al.

\section{PHOTOMICROGRAPHS}
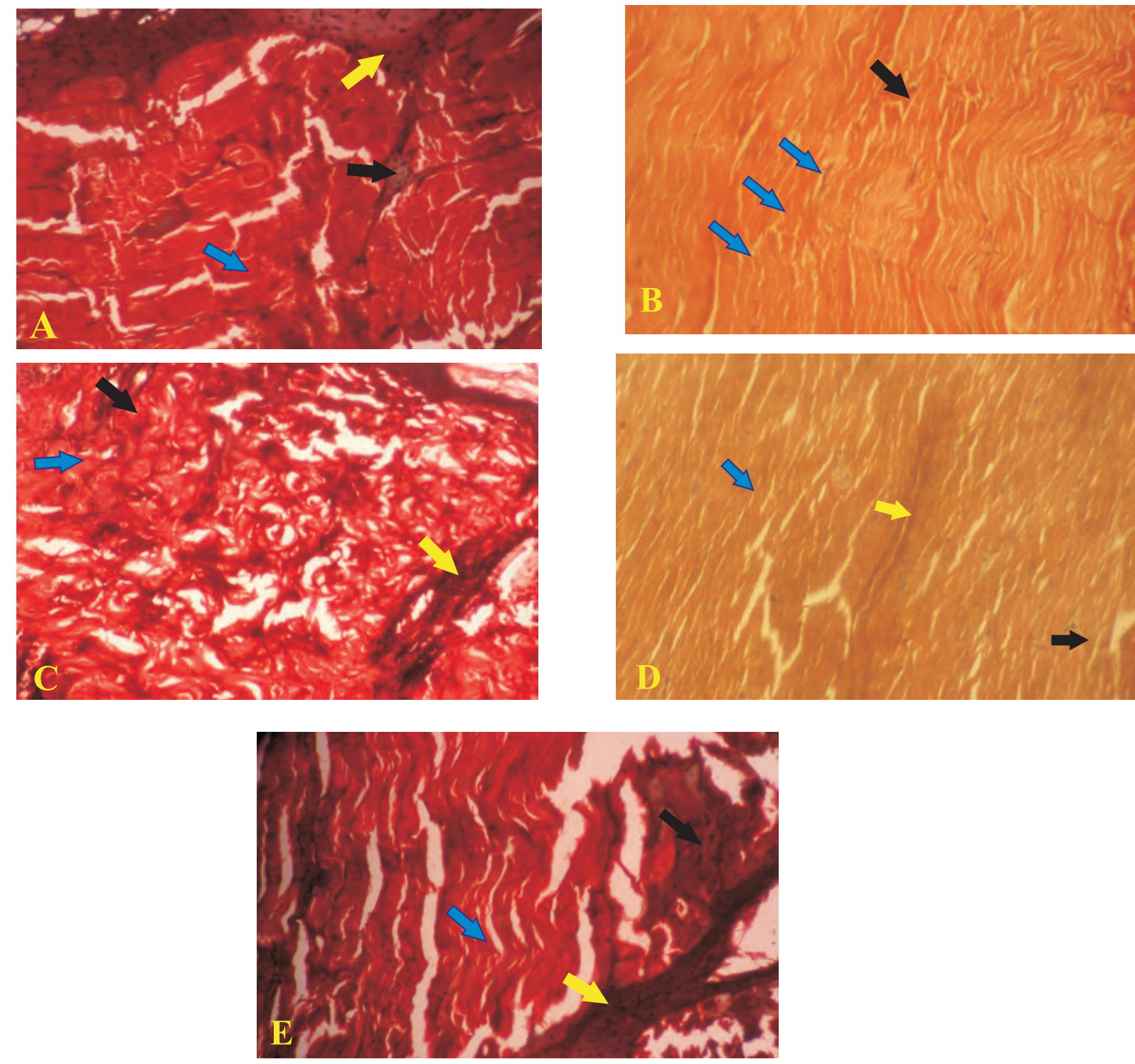

Figure 4: Photomicrograph of the skeletal muscle.

Control (Group A, Plate 1A); Herbal only (Group B. Plate 2 B); Diabetic/STZ induced rats (Group C, Plate 3 C); Diabetic/STZ induced and herbal treatment rats (Group D, Plate 4 D); Diabetic/STZ induced and metformin treatment rats (Group E, Plate 5 E). Masson's trichrome stain; Magnification x 160; the arrows indicate: Yellow: (dense connective tissue epimysium); Black: nuclei in connective tissue; Blue: skeletal muscle fibre. 